\title{
An Analysis into the Contribution of Google Applications in the Successful Implementation of Online Education During the COVID-19 Pandemic
}

Rajeshwari M. ${ }^{1}$, Vinayachandra ${ }^{2}$, Geetha Poornima K. ${ }^{2}$, Krishna Prasad K. ${ }^{4}$

${ }^{1}$ Research Scholar, College of Computer \& Information Sciences, Srinivas University, Mangalore, Karnataka, India and Assistant Professor, Dept of Computer Science, St

Philomena College, Puttur, Karnataka, India

Orcid ID: 0000-0001-9613-4967, E-mail: rajimuraleedhar@gmail.com

${ }^{2}$ Research Scholar, College of Computer \& Information Sciences, Srinivas University, Mangalore, Karnataka, India and Assistant Professor, Dept of Computer Science, St

Philomena College, Puttur, Karnataka, India

Orcid ID: 0000-0002-9374-4871; E-mail: veeciashu@ gmail.com

${ }^{3}$ Research Scholar, College of Computer \& Information Sciences, Srinivas University, Mangalore, Karnataka, India and Assistant Professor, Dept of Computer Science, St

Philomena College, Puttur, Karnataka, India

Orcid ID: 0000-0001-9095-0349; E-mail: poornima.sanjay@gmail.com

${ }^{4}$ Associate Professor \& Post-Doctoral Research Fellow, College of Computer \& Information

Sciences, Srinivas University, Mangalore, Karnataka, India

Orcid ID: 0000-0001-5282-9038; E-mail: krishnaprasadkcci@ srinivasuniversity.edu.in

Subject Area: Business Management.

Type of the Paper: Research Paper.

Type of Review: Peer Reviewed as per $|\mathrm{C}| \mathrm{O}|\mathrm{P}| \mathrm{E} \mid$ guidance.

Indexed In: OpenAIRE.

DOI: https://doi.org/10.5281/zenodo.5091214

Google Scholar Citation: IJAEML

How to Cite this Paper:

M., Rajeshwari, Vinayachandra, K., Geetha Poornima, \& K., Krishna Prasad, (2021). An Analysis into the Contribution of Google Applications in the Successful Implementation of Online Education During the COVID-19 Pandemic. International Journal of Applied Engineering and Management Letters (IJAEML), 5(1), 131-152. DOI: https://doi.org/10.5281/zenodo.5091214

International Journal of Applied Engineering and Management Letters (IJAEML) A Refereed International Journal of Srinivas University, India.

Crossref DOI : https://doi.org/10.47992/IJAEML.2581.7000.0098

(C) With Authors.

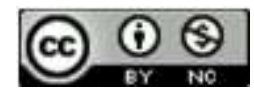

This work is licensed under a Creative Commons Attribution-Non-Commercial 4.0 International License subject to proper citation to the publication source of the work.

Disclaimer: The scholarly papers as reviewed and published by the Srinivas Publications (S.P.), India are the views and opinions of their respective authors and are not the views or opinions of the S.P. The S.P. disclaims of any harm or loss caused due to the published content to any party. 


\title{
An Analysis into the Contribution of Google Applications in the Successful Implementation of Online Education During the COVID-19 Pandemic
}

\author{
Rajeshwari M. ${ }^{1}$, Vinayachandra ${ }^{2}$, Geetha Poornima K. ${ }^{2}$, Krishna Prasad K. ${ }^{4}$ \\ ${ }^{1}$ Research Scholar, College of Computer \& Information Sciences, Srinivas University, \\ Mangalore, Karnataka, India and Assistant Professor, Dept of Computer Science, St \\ Philomena College, Puttur, Karnataka, India \\ Orcid ID: 0000-0001-9613-4967, E-mail: rajimuraleedhar@ gmail.com \\ ${ }^{2}$ Research Scholar, College of Computer \& Information Sciences, Srinivas University, \\ Mangalore, Karnataka, India and Assistant Professor, Dept of Computer Science, St \\ Philomena College, Puttur, Karnataka, India \\ Orcid ID: 0000-0002-9374-4871; E-mail: veeciashu@ gmail.com \\ ${ }^{3}$ Research Scholar, College of Computer \& Information Sciences, Srinivas University, \\ Mangalore, Karnataka, India and Assistant Professor, Dept of Computer Science, St \\ Philomena College, Puttur, Karnataka, India \\ Orcid ID: 0000-0001-9095-0349; E-mail: poornima.sanjay@gmail.com \\ ${ }^{4}$ Associate Professor \& Post-Doctoral Research Fellow, College of Computer \& Information \\ Sciences, Srinivas University, Mangalore, Karnataka, India \\ Orcid ID: 0000-0001-5282-9038; E-mail: krishnaprasadkcci@srinivasuniversity.edu.in
}

\begin{abstract}
Purpose: The emergence of COVID-19 led the world to an unprecedented public health crisis. The outbreak and cause of COVID-19 have placed a wide range of social, political, and economic impacts. The negative impact placed on education is addressed using online education. This paper aims to find success in online education using google applications on regular days and pandemic periods to support the lifelong continuous learning experience. The focus of this study is to review students' satisfaction with the web applications which are mandatory for online education.

Methodology: The non-probability sampling technique is used to collect data for analysis. The new set of hypotheses are identified by using this sampling technique. The exploratory research method is followed to find better results on this topic. Survey questionnaires were prepared and delivered to higher education students of various colleges of various universities in and around our Dakshina Kannada district. The survey including questions on the mode of online education, their level of satisfaction, technologies used, internet facility, internet applications used for the online class. More than 1000 responses were received by the students who are experiencing online education and its platform.
\end{abstract}

Findings/Result: The study aims to decide the regularity of use of the various features of Google applications. Students' opinions toward online learning based on their involvements have been observed. The elements, modes, and tools which designed those students' online education practices have also been considered. The analysis was conducted to identify a variety of applications available for online classroom education with their features that made them so important.

Originality: The features of several internet applications were considered to find popularity in the online mode of education. This analysis may helpful for teachers, students, and administrators even after the pandemic period to conduct additional online courses in a parallel fashion along with traditional classrooms to improve the lifelong learning experience. Paper Type: Survey paper. 
Keywords: COVID-19, Google, Online education, Pandemic Disease, Virtual classroom, Web Applications.

\section{INTRODUCTION :}

The emergence of COVID-19 led the world to an unprecedented public health crisis. The whole world has been shocked by this pandemic disease. The outbreak and cause of COVID-19 have placed a wide range of social, political, and economic impacts. All sections of society have suffered from unpredicted times and situations. Several challenges and issues created in healthcare systems have become more and more. This infectious, pandemic disease targeted well-being and good health, financial level, workforce and style, lifestyle, education, business, and so on. People are forced to face lockdown to avoid the spread of the chain caused by this infectious disease. Digital activities took a major role in all workplaces and 'go digital' became the chant of this lockdown. Students of different age groups have faced psychological problems such as frustration, depression, and stress. Due to the indefinite closure of colleges, educational institutions and students are experimenting with ways to complete their prescribed syllabi within the specified time frame following the academic calendar. These measures have undoubtedly caused some inconvenience, but they have also prompted new examples of educational innovation utilizing digital interventions. To overcome this negative impact, the government made policies and standards of procedure to new classroom protocols. The new learning experiences are created with a virtual classroom or online class environment [1]. The quick development of the Internet as a possible course delivery platform and the technology is now accessible and comparatively user-friendly. Most institutions have moved to an online method during this time, employing Blackboard, Microsoft Teams, Zoom, or other online platforms.

Online education has produced wonderful preferences both inside and outside higher education [2-3]. Online education includes students, teachers, and technologies as key factors. It provides a different learning experience than the traditional classroom. Here the participant's behavior is different and uses technologies for teaching and learning. An effective online learning environment involves a variety of learning and teaching strategies with user-friendly, cost-effective computer technologies and applications. Furthermore, the question of academic integrity has drawn a lot of attention to online education. Fraud and plagiarism are thought to be more prevalent online than in a traditional classroom. In practice, maintaining academic integrity in both delivery forms is a difficulty [4-5].

Student characteristics such as mood, knowledge environment with several teaching methodologies used will add additional factors to improve the quality of online education. Every student owns different levels of psychological learning dimensions and styles. This factor will focus on student senses such as visual, aural, read/write, and kinesthetic used for learning. Sometimes the characteristics of teachers and students are affected by the technologies used. Concerning applications, a few of them are free of cost, timebound, license oriented, limitation on several users, user-friendly interface, and flexibility and data rate. Applications may differ for services or functions they provide to teach one-to-one, one-tomany with video, audio, sharing presenter options, instant messaging/ chat, and polling, etc. will add additional weights to opt higher level of motivation through online learning. Each application and usage will imply varying levels of satisfaction in the online learning experience [5-8].

Web applications and their functions may play an important role in bridging the gap between teachers, students, and an institution. They enable continuous connection and collaboration even at any distant place. The web applications provide simple, easy procedures to set up virtual classrooms and allow joining many students into it. They keep track of dates and events by calendars, sending notifications and reminders to students, teachers, and parents of virtual classes. Students can continue at their own pace through needed activities and self-assessments using communicating tools such as simulations or self-administered competitions. This may help the teacher to keep track of every student to study his performance [9-10].

Education can be elevated during the pandemic period by using an online learning environment. The demand for simple, flexible, and secure tools is supplied with Google web applications. Unlimited learning opportunities are given through thousands of such Google and educator-approved apps supported by smartphones and computers to integrate classroom activities and spark creativity in the online education environment. Most of them are free of cost, easy to use with enhanced capabilities to suit the requirements of an educational institution. Many higher education institutions found that Google Apps are effective and cost-efficient solutions for online education [11]. Smartphones and computer- 
compatible applications are widely used anywhere, anytime around the world. Strong and secured infrastructure is created with such applications to maintain data privacy and security. Google-based such applications enhance programming interfaces to satisfy the state of art feature for information collaboration between teachers, students, and administration persons of the institution. Huge online data storage for emails, calendars for sharing event details such as meetings, classes, etc., instant chatting, online information collaboration such as creating documents, spreadsheets, and presentations. Google Docs and team web sites development with Google sites to gather all types of information such as notes, presentations, files, class videos, and many more gadgets. One-to-one and one-to-many sharing of text, audio, video, and chat sessions are also supported by Google Hangouts to fulfill the demand for interactive virtual classrooms [12-13].

Finally, student learning outcome has to be decided based on the knowledge received through this online virtual classroom [14]. The educational institution may find a way to teach multiple students virtually, with distance, but student satisfaction and opinion will be collected to find the best mode of education such as face-to-face classroom experience, online education, or blended education system [15-17].

\section{REVIEW OF LITERATURE :}

According to Yang \& Cornelius [7], even though several types of research focus on teacher's and administrator opinions, there has been little study on students' overall excellence or superiority with online education. The literature review is conducted on internet applications used in online education and student's satisfaction with their learning experience in this direction.

\subsection{Virtual education applications}

Li et al [18] found that web-based conferencing and education have grown in popularity as a result of technological advancements. During the COVID-19 pandemic, education is a challenge. The expertise of major components of video-conferencing technology set-up, execution, and possible risks in the implementation of virtual read-outs can help to advance the educational practice of radiology learners and promote future potential distance collaborative learning. Radiology trainees are in charge of training the method of diagnosis and treatment. The current technology will provide maximum training facilities both during the crisis and on regular days.

The system, as well as the experience learned by educators, students, and university administration, could be applied in the post-pandemic period, in the occasion of missed lessons or other comparable distinctive cases. Basilaia \& Kvavadze [19] studied that the professors have re-created distance learning in a new way, adapting assigned tasks to the new system of the lessons, which will impact their qualifications. Online education can be beneficial in the post-pandemic duration, particularly for pupils with special needs. Extra time will be used for individually verifying assignments and reverting feedback, which is one way to improve group teaching effectiveness. Here, students can work more independently, which is a benefit of learning new skills.

To ensure better learning and further improve educational quality, Chen et al [20] discovered that the platform must actively find innovative informational formats, such as "you ask me to answer," "face to face," "students record learning videos," and "real-time lecture."

Learners took part in the asynchronous video discussions, and it appeared that they valued the ability to see and understand their instructors and peers at a moment that was helpful for them. Yaman, N., \& Muhlis [21] discovered that the technology used in online education was capable of reaching and supporting every student.

Laksana [22] found that people can enhance the quality of learning through digital learning by increasing access to information and delivering high-quality education, particularly through the use of greater and increased approaches. Education information technology systems provide a wide, quick, efficient, and reliable coverage of disseminating information to various parts of the world.

According to Krutka et al [23], Google designed its apps, along with the default and advanced settings, to reach individual students beyond geographical boundaries. Google has created several applications with the mission of organizing information all over the world. The COVID-19 outbreak demonstrated how quickly digital tools can be integrated into educational programs that leave students with few options, exposing inequities in digital access.

\subsection{Student Satisfaction and learning experience}


Students' lack of learning activities, reasoning skills, and the ability to discuss and express their views, intentions that the higher education system did not develop, are now becoming prominent in the higher education system during the online learning experience. Students have strategies for preventing activities that require critical thinking, debate, or simply stating their viewpoint, and educators have little authority over them. Coman et al [24] emphasize the fact that most students are using them as an attempt to ignore active involvement in classes.

According to Mishra et al [25], for Indian teachers in general, online teaching is an exciting concept. Initially, attendance was low, but as time went on, the race gained popularity, and students felt very comfortable attending classes online. Due to not adhering to the schedule as in normal classrooms, the timing of online classes occasionally came into conflict with other faculty, as reported by teachers from different departments. Furthermore, teachers acknowledged that they were unable to completely resolve students' doubts and satisfy students' satisfaction levels due to the various challenges they encountered in the early stages of online teaching-learning.

Around half of the respondents agree that online learning improves their technological expertise more than face-to-face classes. It is also clear that approximately a 60percent of respondents agree with the assertion that online classes are a little less effective when it comes to interaction with the instructor when tried to compare to face-to-face classes. In terms of the aforementioned criteria, 20-30percent of the total respondents believe that online and face-to-face classes are equally effective. The results prepared by Muthuprasad et al [26] also revealed that there was neither complete disagreement nor complete agreement among the survey participants concerning the efficacy of online learning.

Tang et al [27] findings show that there was no statistically significant difference between the genders of students. However, the mean scores in preparing students for live online learning differed significantly between PG and UG students. According to the post hoc testing results, PG students are more motivated to start understanding than UG students. In addition, PG students have greater technological readiness, learner control, and self-directed learning ability than UG students. However, there was no notable change in digital communication self-efficacy.

Paudel [28] discovered that the respondents recommended online education as an alternative method, and blended learning may be better in the present scenario, where there is no reliable internet connection in work environments and students and teachers are not fully technologically savvy. It, therefore, implies that blended learning can play a significant role in Nepal's higher academic setting if its execution is tailored to the learners' requirements, levels, interests, and situations while addressing both cognitive and emotional domains. At the very same time, academic institutions should formulate control strategies to create policy, educational setting, curriculum content, instructors, and learners friendly to blended learning, so that equity between online education and face-to-face mode of learning and teaching is achieved.

\section{OBJECTIVES :}

(1) To analyze the technologies used by students for online education.

(2) To identify the Google applications and their purpose in education.

(3) To study the Students' perceptions toward online education based on their own experiences

(4) To investigate the factors, modes, and tools that shaped those students' online education experiences.

\section{HYPOTHESIS :}

- $\mathrm{H}_{1}$ : Google does not play a significant role in the field of online education.

- $\mathrm{H}_{2}$ : There is no significant difference among male and female students' perceptions of on-campus education as their preferred mode of education.

- $\mathrm{H}_{3}$ : There is a significant difference in perceptions of WhatsApp as the preferred medium for communication with teachers among male and female students.

\section{SCOPE OF THE STUDY :}

The primary goal of this research is to identify the most commonly used Google applications in online education environments, as well as their frequency of use and impact on students' learning experiences during the COVID-19 pandemic period. A Google form with 53 questionnaires was created and distributed to students from various districts in Karnataka and Kerala. The responses are cleansed and 
analyzed in an attempt to discover answers to the following questions to meet the demand for educational opportunities impacted by the pandemic outbreak.

- What technologies and software are available for online learning?

- What are the factors that have contributed to Google applications becoming more popular and effective in the field of education?

- Are the students satisfied with the use of these applications while learning in virtual mode?

- Do the students agree to continue their learning journey using the same virtual model of education?

The survey had a very limited number of questionnaires. To assess the performance of virtual classrooms, only students' perceptions are taken into account. The majority of the questions were objective, with only a few allowing you to select multiple options. Users were not given the option of writing short or long responses to share their thoughts or opinions.

\section{METHODOLOGY :}

A survey questionnaire was used to collect data, which was distributed for a week to various colleges and universities in and around our Dakshina Kannada district, as well as a few districts in Kerala. Students from higher education who have been exposed to online education and its platform have responded. There were survey questionnaires that attempted to collect information on student characteristics, technology and web applications used for online education, and student experience with internet applications for online education. More than 1500 responses from neighboring higher education institutions, including undergraduate, graduate, and professional colleges and universities, were received until May 5th, 2021. A Google form (https://forms.gle/ HcyELW1fQjBq1QLM8) was used to prepare 53 questions, which were then verified by an Associate Professor of Economics. The questions were divided into four groups. Section A of the survey contained demographic information about the respondents, Section B housed questionnaires about technology-assisted education, Section C includes items about students' knowledge and experience, and Section D encompassed questions about the respondents' exposure and experience. After collecting all of the responses, they were cleansed to yield 1241 responses, from which a few hypotheses on online education for data analysis on Google applications and student perception were derived. A non-probability sampling technique was used to process the data for analysis. The exploratory research method was used to achieve good results.

The parameters were analyzed based on Teacher efficacy, Technology, Instructor attributes, Student characteristics, implementations used in various areas of digital learning, which will be represented in tabulated and pictorial form in the following sections. Because of its robustness in terms of data distribution, the chi-square test model is used for hypothesis testing. Ultimately, some suggestions and recommendations were made to various stakeholders in the higher education system based on the findings.

\section{GOOGLE TOOLS FOR EDUCATION :}

Google provides several cloud-computing applications and most of those applications are well suited for offline and online learning. A successful online learning environment incorporates a variety of teaching and learning strategies with user-friendly, low-cost computer technologies and applications. Applications like 


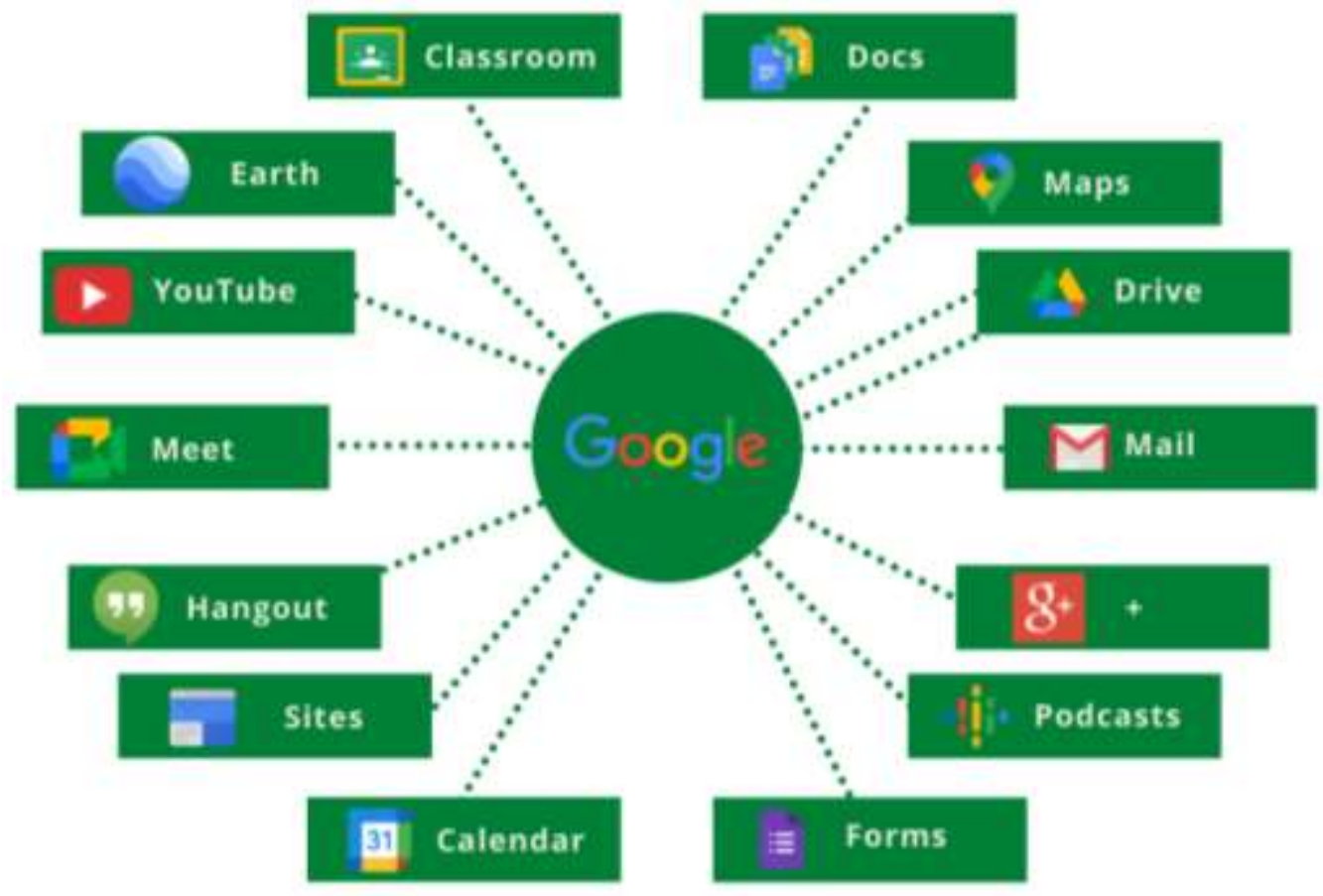

Fig 1: Most common Google tools used for online education

Google Meet, Google Hangout enables face-to-face connections with students to set the same mood created in the physical classroom. Learners and teachers can connect from anywhere with a hybrid approach with such applications. High-level data security and privacy are also the additional features of these classroom web applications. Each user s ensured with a unique sign-in procedure to maintain individual accounts secure and private. Exclusive members with the links can involve in the activities conducted in the classroom [29]. The most common education-related Google apps provided by G-suite are Gmail, Google Drive, Google Calendar, and YouTube, etc. Several colleges and universities have become partners with Google to face the challenges made by the COVID-19 pandemic on teaching and learning. Customized versions of Google applications play an important role in the enhancement of communication between students and teachers in Higher education. Additional storage space, spam detection, chat services, event handlers, and customized emails are some additional services that improve the quality of Google tools. Some of the most popular tools (Figure-1) of Google are listed and explained below.

- Google Classroom: A Google classroom creates virtual classrooms, record lessons and collect student works and provides mechanisms to award grades towards motivation of students in their learning process. It allows the best possible communication between teacher and students through email as well as conversation with the individual and all students within the same interface [12]. The data shared such as class notes, instructions given to the students, materials, videos are stored with high-security mechanisms on the cloud. Easy mechanisms to conduct exams, quizzes and group discussions, etc. are also facilitated with the easy maintenance of grades of each student involved in the classroom. Online forms provided by these classrooms make the users share learning curriculum, announcements, lessons, assignments, feedback, etc. [30]

- Google Docs: These are free, cloud-based tools used for creating word documents. Hence they are the best alternative solutions for Microsoft Word documents. These paperless docs can be used to write essays, notes, papers, and so on by the students and teachers which in turn highlight the concept of Go Green. These also make the teacher ask for assignments and turn in the Google classroom. A group of students working on a project can use these Google Docs for their collaborative assignments and reports. These will provide a built-in chat module for best teamwork among students [31].

- Google Drive: A huge 15GB free storage is given by Google using its drive for its users. It saves data files with different file formats such as pdf, video, audio, documents, and more with easy access and security. Data or files cannot be used by other Google users unless permission is granted. 
This will offer the neat organization and collaboration of user files through easy share, view, and download options with other users such as teachers, students, and management staff. These drives allow users to access their data files online or offline depending on the setting made by them.

- Google Forms: Easy, Self-grading tests and exams can be prepared by using Google Forms. They allow teachers to create quizzes and other assessments. The forms are AutoSaved on clouds using Google Drives. These secure forms allow teachers to conduct tests with or without answer keys. This functionality can be enhanced by other compatible Add-ons like Flubaroo to assign tests to a specific student, record responses, and results will be posted to both student and parent.

- G-mail: Gmail is the most commonly used online learning application. Gmail allows people to contact each other from anywhere and at any time, track upcoming events, and securely share data files. Course notifications, lesson plans, remainders, and student instructions can all be shared. Gmail also includes text, audio, and video sharing, chat services, and one-on-one tutoring sessions. Gmail users have access to a large amount of storage via Google Drive. While the Lecturers share resources, all emails can include signatures. Emails are well organized using labels, groups, and filters, allowing users to sort messages by category [13].

- Google+: Teachers can maintain a constant touch with their peers using the social network offered by Google+. They can share photos and status updates to the stream or interest-based communities, groups, with multi-person instant messaging, text and video chats, events, location tagging. It has become more popular with the ability to edit and upload photos to private cloud-based albums. This may help in keeping up with the latest trends in education, get much-needed support, and participate in lively discussions with fellow educators [30].

- YouTube: A high-quality videos can be shared by teachers as well students very easily with proper user Google accounts. It makes the teachers share their classes through a wide range of student groups along with comments and view counts. YouTube has become the second-highest search engine for video resources [16].

- Google Meet: Google Meet is constantly evolving and adding new features to give educators more control over their reflective teaching and to increase engagement in virtual classes. With secure access, it manages attendees and content quickly and easily. Here, moderators or teachers can lock the activities that take place during video sessions. They can share the user's screen, lock chat options to limit conversations, and quickly mute individual or all participants to ensure smooth live sessions. Teachers are only permitted to admit students from within or outside the institution's domain. This will prevent uninterested attendees from attending the classes. Google Meet attaches to the highest education security measures, so you can always rely on safe encrypted data and stringent anti-abuse measures to preserve rigorous confidentiality and compliance. Google Meet, which is free, can accommodate 100 participants at a time and offers key features such as Host setting to start, end, and control live classes, Raising hand options to join discussions, the larger tiled window allows you to see 49 students at once, Digital whiteboarding to provide pdfs for participants to work on during the session. Live captions in multiple languages to engage various types of learners, Moderation controls are in place to allow users to share, talk, and chat. Paid and updated Google Meet applications can accommodate up to 250 students and provide some additional features not listed above. They are Breakout Rooms, which divide students into smaller groups, Q\&A and polling, which engage students in classes by asking questions and submitting answers, respectively, and an attendance report of participants. These meetings can be recorded and archived directly into Drive. To avoid distraction or disturbance in the classroom, the Intelligent Noise Cancellation feature will be used to ensure smooth classroom engagement [16].

- Google Hangout: Learners can be encouraged to collaborate via Gmail Video, also known as Gmail Hangouts. Through the application, students are asked to carry out a real-life scenario or problem-solving task together. This allows students to study and learn from the experiences of others while also developing teamwork skills. This app also provides free group video calls using a Gmail account. As a result, multiple or a group of students can participate in such video conversations at the same time to enjoy the benefits of learning.

- Google Maps and Google Earth: Directions for driving and 360-degree view around the globe is very easily seen by the most popular online tool called Google Maps. Geography lessons can make use of such map tools as virtual Atlas in the virtual classes. Google Earth will provide a 3D view 
of the globe. Students can take a virtual trip using such an amazing application. With Google Earth and mapping tools, people can gain knowledge about diverse cultures in biomes and cities, track how a river's shape has changed over the years, or start creating a project showcasing architectural styles from different eras. Using Google Earth and Maps in the classroom helps students visualize abstract ideas across a worldwide canvas, able to connect what they learn on the inside to what they experience in their daily lives, communities, and the larger world [16].

- Google Calendar: Another Google tool, Google Calendar, allows the teacher to schedule, prepare a to-do list, set reminders, and so on. Parent-teacher conferences can be scheduled and confirmed using such a calendar. Lesson plans will be prepared and uploaded to the virtual classroom or website. These scheduled calendars can be shared among students or parents for them to be aware of each other's schedules and to provide a mechanism for preparing a timetable with no overlaps [19].

- Podcasts: Google Podcasts is a podcast application that also has a web version for iOS, Android, and Windows. A podcast is an episodic series of spoken word digital audio files which can be taken to a personal device and listened to. Podcasts can be created from audio conferences that have been recorded. A podcast collection is typically featured by one or more rotating hosts taking part in a conversation about a specific subject or event. In a podcast, the discussion and content can vary from thoughtfully screened to entirely improvised. Most podcast series include links, reveals of guest biographies, transcripts, upgrades, reviews, and even a group forum where students can debate the class content [9].

- Google Sites: Google Sites is being used to showcase students' work with the rest of the school community, to start creating a portal for your class, and to create and organize online resources. Google Sites is a website builder that lets you easily drag-and-drop templates. In addition to the ease of use, there are numerous upload options, including images, videos, and maps. Students can embed Google Docs, Forms, and Slides into their websites, and everything updates automatically as anyone edits the documents in their Drive. The teachers can set up a webpage for their class that includes course materials as well as rich content such as videos, images, slides, and audio recordings. Then they will be able to use it to post homework, assignments, and class events. Students can also set up and manage to-do lists for their tasks and classroom activities, as well as for project group collaboration. They can use it to deliver their research findings on a specific research topic. They can include documents they have created, videos, links, and many other things. Learners can also use it to assist with course materials and make a contribution to knowledge building in the classroom [10].

\section{DATA ANALYSIS AND INTERPRETATION :}

The survey began with the creation of a Google Form, which contained approximately 53 questions about the mode of online education, degree of satisfaction, internet access, and the technologies and applications used. The form's URL is shared with students via WhatsApp and other social media platforms. Over 1500 responses have been submitted by higher education students from several districts in Karnataka and a few from Kerala who was exposed to online education and its platform. Table-1 shows the demographics of the students who responded to the survey. Data analysis is limited to the 1241 responses that remained after cleaning the data. There are $725(58 \%)$ female students and 516 (42\%) male students among the total 1241 respondents, with 1018 (82\%) Under Graduate (UG) and $223(18 \%)$ Post Graduate (PG) degrees. Even though the students in the survey are from urban areas $822(66 \%)$, rural areas 273(22\%), and semi-urban areas 146(12\%); 1215(98\%) are educated in English, while only $26(2 \%)$ are educated in Kannada. Students enrolled in higher education institutions may have differing perspectives on the type of institution. As a result, the type of institution is also taken into account in this data analysis.

Table 1: Profile of respondents

\begin{tabular}{|l|l|l|l|}
\hline Variable & Options & Frequency & Percentage \\
\hline Gender & Male & 516 & 42 \\
\cline { 2 - 4 } & Female & 725 & 58 \\
\cline { 2 - 4 } & Total & 1241 & 100 \\
\hline
\end{tabular}




\begin{tabular}{|l|l|l|l|}
\hline \multirow{4}{*}{$\begin{array}{l}\text { Education } \\
\text { Level }\end{array}$} & UG & 1018 & 82 \\
\cline { 2 - 4 } & PG & 223 & 18 \\
\cline { 2 - 4 } & Total & 1241 & 100 \\
\hline \multirow{4}{*}{$\begin{array}{l}\text { Medium of } \\
\text { Instruction }\end{array}$} & Rural & 273 & 22 \\
\cline { 2 - 4 } & Suburban & 146 & 12 \\
\cline { 2 - 4 } & Urban & 822 & 66 \\
\cline { 2 - 4 } & Total & 1241 & 100 \\
\cline { 2 - 4 } & Kannadish & 1215 & 98 \\
\cline { 2 - 4 } Type & Total & 26 & 2 \\
\hline \multirow{4}{*}{\begin{tabular}{l} 
Tytitution \\
\cline { 2 - 4 }
\end{tabular}} & Aided & 1241 & 100 \\
\cline { 2 - 4 } & Government & 50 & 17 \\
\cline { 2 - 4 } & Private & 966 & 100 \\
\cline { 2 - 4 } & Sponsored & 15 & 78 \\
\hline
\end{tabular}

According to the table-1, among the students pursuing their graduation, 50 (4\%) join government colleges, 210 (17\%) join Aided colleges, 966 (78\%) join private colleges, and a very small percentage $15(1 \%)$ join sponsored colleges. Online or virtual education necessitates the use of both hardware and software. Each device and compatible technology may provide a unique set of experiences and perspectives on online education. Table- 2 displays the most commonly used devices for attending online classes. It emphasizes the fact that 1056 of the higher education students own smartphones (85.09 $\%), 145(11.68 \%)$ utilize laptops, $8(0.64 \%)$ choose personal computers, $10(0.81 \%)$ are using smart $\mathrm{TV}$, and $8(0.64$ percent $)$ use tablets for their online classes.

Table 2: Device prominently used by students for attending online classes

\begin{tabular}{|c|c|c|}
\hline Options & Count & \% \\
\hline Laptop & 145 & 11.68 \\
\hline Personal Computer & 8 & 0.64 \\
\hline Smart Phone & 1056 & 85.09 \\
\hline Smart TV & 10 & 0.81 \\
\hline Tablet & 8 & 0.64 \\
\hline None & 14 & 1.13 \\
\hline Grand Total & 1241 & - \\
\hline
\end{tabular}

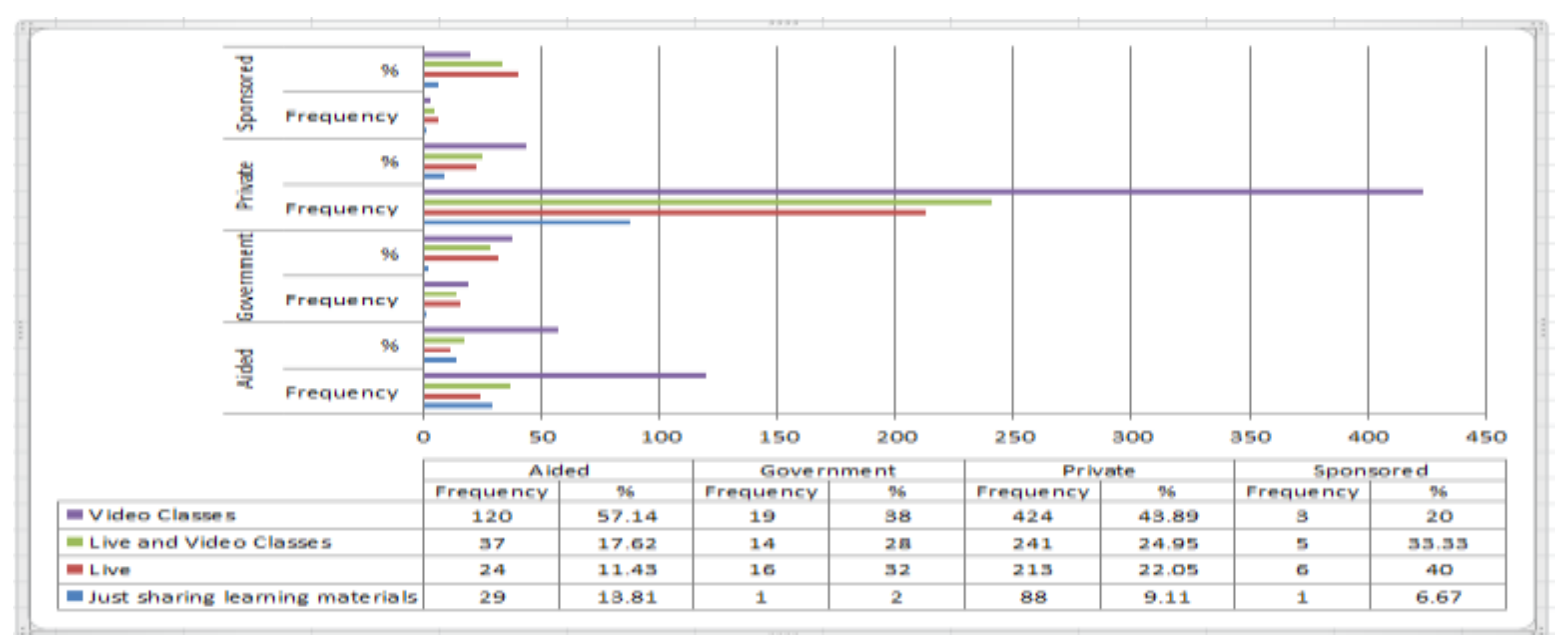

Fig 2: Mode of online class delivery to students 
During the COVID-19 pandemic period, the most affected area is education and associated factors and people. The urge of getting knowledge is to be satisfied by online education. The institutions that provide virtual education in this period may or may not be satisfied. The data acquired on the survey (Table-3) found that online education is excellent only by 27(2.18\%), feeling as Good by 357(28.77\%), as average by $542(43.67 \%)$, and as poor by $145(11.68 \%)$ students. The remaining $170(13.7 \%)$ of students are still not interested to attend the online classes.

Table 3: Students perception towards online education

\begin{tabular}{|l|r|r|r|r|r|r|}
\hline Options & \multicolumn{2}{|c|}{ Female } & \multicolumn{2}{c|}{ Male } & \multicolumn{2}{c|}{ Total } \\
\hline & Frequency & Percentage & Frequency & Percentage & Frequency & Percentage \\
\hline Excellent & 17 & 2.34 & 10 & 1.94 & 27 & 2.18 \\
\hline Good & 251 & 34.62 & 106 & 20.54 & 357 & 28.77 \\
\hline Average & 338 & 46.62 & 204 & 39.53 & 542 & 43.67 \\
\hline Not interesting & 76 & 10.48 & 94 & 18.22 & 170 & 13.7 \\
\hline Poor & 43 & 5.93 & 102 & 19.77 & 145 & 11.68 \\
\hline
\end{tabular}

During the pandemic period, the institutions conducted online classes in various modes based on the flexibility, requirements, and convenience of the technology and online applications provided by various IT companies. Some educational institutions will provide the necessary training, materials, and facilities to conduct online classes. As a result, the type of institution and mode of delivery of online classes to students must be taken into account when interpreting the data. The cost of the devices, the required technology and applications, internet charges, and coverage are all factors that will influence the mode of delivery. According to a survey, the majority of private colleges (43.89\%) prefer video classes to other methods such as live and video classes (24.95\%), live classes (22.05\%), and simply sharing learning materials $(9.11 \%)$. Aided colleges are doing the same thing as private colleges. $57.14 \%$ of aided colleges offer video classes, 17.62 percent offer live and video classes, $11.43 \%$ offer exclusive live classes, and 13.81 percent simply distribute learning materials to students. A study also shows that government colleges are more likely to hold video classes (38 percent) than live and video classes (28 percent), live sessions (3\%) and share learning materials (2\%). However, the majority of sponsored colleges (40\%) are taking live classes, $33.33 \%$ are delivering lectures via both live and video classes, $20 \%$ are using video classes via available internet applications, and a few, 6.67 percent, are still sharing learning materials. Figure 2 depicts the entire scenario. According to the statistics, the most common method of delivering online classes by most institutions is through the sharing of video classes.

Because of the educational challenge posed by the COVID-19 outbreak, virtual education has grown in popularity. Students must attend online classes regularly, just as they do face-to-face classes. According to the survey results, the majority of students are degree and postgraduate students who are compelled to attend online classes. They will require blended education, which will include both physical and virtual classes. Table 4 displays the survey data collected to learn about the importance of online education in the minds of learners. Students were aware of the pandemic situation, and degree students responded with average significance (53.14 percent), while post-graduate students agreed with the same opinion (42.15 percent), despite their familiarity with mobiles and technologies. Still, some degree (16.99 percent) and postgraduate (25.56 percent) students, both male and female, believe that virtual education is ineffective. Some degree (20.14 percent) and post-graduate (22.87 percent) students have concluded the significance by selecting the response "Partially effective." Only 8.35 percent and 1.38 percent of degree students, as well as 4.48 percent and 4.93 percent of post-graduate students, thought online education was very effective or extremely effective.

Table 4: The significance of online education in the views of students

\begin{tabular}{|r|r|r|r|r|r|r|}
\hline \multirow{2}{*}{ Options } & \multicolumn{2}{|c|}{ Degree } & \multicolumn{2}{c|}{ Post-Graduation } & \multicolumn{2}{c|}{ Grand Total } \\
\cline { 2 - 7 } & Frequency & \multicolumn{1}{c}{$\%$} & Frequency & \% & Frequency & \multicolumn{1}{c|}{} \\
\hline Extremely Effective & $\mathbf{1 4}$ & $\mathbf{1 . 3 8}$ & $\mathbf{1 1}$ & $\mathbf{4 . 9 3}$ & $\mathbf{2 5}$ & $\mathbf{2 . 0 1}$ \\
\hline Female & 8 & 57.14 & 6 & 54.55 & 14 & 56 \\
\hline Male & 6 & 42.86 & 5 & 45.45 & 11 & 44 \\
\hline Very Effective & $\mathbf{8 5}$ & $\mathbf{8 . 3 5}$ & $\mathbf{1 0}$ & $\mathbf{4 . 4 8}$ & $\mathbf{9 5}$ & $\mathbf{7 . 6 6}$ \\
\hline
\end{tabular}




\begin{tabular}{|r|r|r|r|r|r|r|}
\hline Female & 51 & 60 & 7 & 70 & 58 & 61.05 \\
\hline Male & 34 & 40 & 3 & 30 & 37 & 38.95 \\
\hline Partially Effective & $\mathbf{2 0 5}$ & $\mathbf{2 0 . 1 4}$ & $\mathbf{5 1}$ & $\mathbf{2 2 . 8 7}$ & $\mathbf{2 5 9}$ & $\mathbf{2 0 . 8 7}$ \\
\hline Female & 107 & 52.2 & 36 & 70.59 & 145 & 55.98 \\
\hline Male & 98 & 47.8 & 15 & 29.41 & 114 & 44.02 \\
\hline Average & $\mathbf{5 4 1}$ & $\mathbf{5 3 . 1 4}$ & $\mathbf{9 4}$ & $\mathbf{4 2 . 1 5}$ & $\mathbf{6 4 1}$ & $\mathbf{5 1 . 6 5}$ \\
\hline Female & 346 & 63.96 & 74 & 78.72 & 424 & 66.15 \\
\hline Male & 195 & 36.04 & 20 & 21.28 & 217 & 33.85 \\
\hline Not at all Effective & $\mathbf{1 7 3}$ & $\mathbf{1 6 . 9 9}$ & $\mathbf{5 7}$ & $\mathbf{2 5 . 5 6}$ & $\mathbf{2 3 2}$ & $\mathbf{1 8 . 6 9}$ \\
\hline Female & 57 & 32.95 & 33 & 57.89 & 90 & 38.79 \\
\hline Male & 116 & 67.05 & 24 & 42.11 & 142 & 61.21 \\
\hline
\end{tabular}

Because of user-friendly technologies and applications, online education will become more popular and satisfying. The new products have become popular and cost-effective, and they can be used in a variety of settings. To set up virtual classroom environments in an online or virtual education environment, the best, most flexible, compatible, secure, and cost-effective solutions are required. According to the survey (Table 5), 37.61 percent of degree and 42.95 percent of PG female students, as well as 40.09 percent of degree and 40.3 percent of PG boys, have moderate satisfaction with such technologies and software. Table 5 also highlights many other possible responses to the same question from male and female degree and post-graduate students. This demonstrates that, even as technology becomes more popular, students still require a traditional mode of education in addition to modern applications and gadgets.

Table 5: Students' satisfaction with the technologies and software that teachers use for online education.

\begin{tabular}{|c|c|c|c|c|c|c|}
\hline Options & Degree & $\%$ & PG & $\%$ & Total & $\%$ \\
\hline Female & 569 & 55.89 & 156 & 69.96 & 725 & 58.42 \\
\hline Extremely satisfied & 27 & 4.75 & 2 & 1.28 & 29 & 4 \\
\hline Very satisfied & 159 & 27.94 & 33 & 21.15 & 192 & 26.48 \\
\hline Moderately satisfied & 214 & 37.61 & 67 & 42.95 & 281 & 38.76 \\
\hline Slightly satisfied & 137 & 24.08 & 41 & 26.28 & 178 & 24.55 \\
\hline Not at all satisfied & 32 & 5.62 & 13 & 8.33 & 45 & 6.21 \\
\hline Male & 449 & 44.11 & 67 & 30.04 & 516 & 41.58 \\
\hline Extremely satisfied & 27 & 6.01 & 0 & 0 & 27 & 5.23 \\
\hline Very satisfied & 68 & 15.14 & 12 & 17.91 & 80 & 15.5 \\
\hline Moderately satisfied & 180 & 40.09 & 27 & 40.3 & 207 & 40.12 \\
\hline Slightly satisfied & 100 & 22.27 & 17 & 25.37 & 117 & 22.67 \\
\hline Not at all satisfied & 74 & 16.48 & 11 & 16.42 & 85 & 16.47 \\
\hline
\end{tabular}

Effective communication is a fundamental component of any educational system. Communication between teachers and students occurs in a variety of ways during the traditional teaching-learning process. Face-to-face communication provides teachers with immediate feedback. Teachers can tell whether a student is paying attention in class and whether the concept being discussed is clear to the student simply by observing their facial expressions. The facial expressions of both parties involved in communication are very important in making communication more effective. In live interaction, students can effectively communicate with their teachers and also with their peers. Face-to-face communication improves learning abilities and enhances recollection. There will be greater understanding between the teachers and students. Students nowadays communicate via text messages and instant messaging. Table-6 displays student feedback on the importance of face-to-face communication. In the opinion of undergraduate students, 16.6 percent believe it is extremely important, 30.45 percent believe it is very important, 27.21 percent believe it is moderately important, 
15.91 percent believe it is slightly important, and 9.82 percent believe it is not at all important to have face-to-face communication during online learning. 14.35 percent of PG students rated it as extremely important, 38.12 percent rated it as very important, 27.80 percent rated it as moderately important, 11.66 percent rated it as slightly important, and only 8.07 percent rated it as not at all important. Face-to-face communication is very important to $48 \%$ of respondents, and it is helpful to $42 \%$ of them in some way. Only around $10 \%$ of students believe it is unimportant.

Table 6: Students feedback on the importance of face-to-face communication while learning remotely

\begin{tabular}{|l|r|r|r|r|r|r|}
\hline Options & \multicolumn{1}{|c|}{ Degree } & \multicolumn{1}{c|}{$\%$} & \multicolumn{1}{c|}{ PG } & \multicolumn{1}{c|}{$\%$} & \multicolumn{1}{c|}{ Total } & \multicolumn{1}{c|}{$\%$} \\
\hline Extremely important & 169 & 16.6 & 32 & 14.35 & 201 & 16.2 \\
\hline Very important & 310 & 30.45 & 85 & 38.12 & 395 & 31.83 \\
\hline Moderately important & 277 & 27.21 & 62 & 27.8 & 339 & 27.32 \\
\hline Slightly important & 162 & 15.91 & 26 & 11.66 & 188 & 15.15 \\
\hline Not at all important & 100 & 9.82 & 18 & 8.07 & 118 & 9.51 \\
\hline
\end{tabular}

Learning new things keeps the mind fresh and engaged even when students are stuck at home due to lockdown. It is the best way to keep a person active and healthy. From the technology point of view, it is for self-development and to maintain one's relevance. Students may learn more, gain more knowledge, discover new things, and think out of the box while still at home, according to proponents of online education. This is owing to the available internet resources, as well as the chances and exposure gained. This argument does not persuade students, according to the survey results. Only 58\% of students feel that online education has helped them learn new skills while at home, while $42 \%$ disagree fully. It is summarized in Table-7 below.

Table 7: Student's perspective on learning new things, though they are at home

\begin{tabular}{|r|r|r|r|r|r|r|}
\hline \multicolumn{1}{l|}{ Options } & \multicolumn{1}{l|}{ Female } & \multicolumn{1}{l|}{$\boldsymbol{l}$ Male } & \multicolumn{1}{l|}{ \% } & \multicolumn{1}{l|}{ Total } & \multicolumn{1}{l|}{} \\
\hline Degree & 569 & 78.48 & 449 & 87.02 & 1018 & 82.03 \\
\hline Strongly Agree & 31 & 5.45 & 27 & 6.01 & 58 & 5.7 \\
\hline Agree & 326 & 57.29 & 208 & 46.33 & 534 & 52.46 \\
\hline Disagree & 177 & 31.11 & 152 & 33.85 & 329 & 32.32 \\
\hline Strongly disagree & 35 & 6.15 & 62 & 13.81 & 97 & 9.53 \\
\hline Post-Graduation & 150 & 20.69 & 62 & 12.02 & 223 & 17.97 \\
\hline Strongly Agree & 5 & 3.33 & 2 & 3.23 & 7 & 3.14 \\
\hline Agree & 94 & 62.67 & 29 & 46.77 & 123 & 55.16 \\
\hline Disagree & 47 & 31.33 & 24 & 38.71 & 71 & 31.84 \\
\hline Strongly disagree & 10 & 6.67 & 12 & 19.35 & 22 & 9.87 \\
\hline
\end{tabular}

The purpose of education is to provide learners with practical and theoretical knowledge. Students gain knowledge through their experiences. Experiments can be used to introduce new concepts or clarify unclear aspects of topics that students struggle with commonly. Students will be able to bear the consequences of the new concept and use it to scaffold learning if the result of an experiment is unexpected but interesting. Theoretical knowledge aids in the comprehension of concepts, however practical experience provides more in-depth perspectives into subjects based on personal experience. It is impossible to operate the equipment from home during online classes. Teachers can benefit from live demonstrations, simulations, and virtual labs when conducting practical sessions. As shown in Table-8 online classes, according to $72 \%$ of respondents, did not provide adequate academic and practical experience. In comparison to UG students, PG students (80\%) are more concerned about the issue (70\%). Furthermore, female students are slightly less concerned than male students.

Table 8: Students' feedback on theoretical and practical experiences gained through online education

\begin{tabular}{|c|c|c|c|c|c|c|}
\hline Options & UG & $\%$ & PG & $\%$ & Grand Total & $\%$ \\
\hline Female & 569 & 55.89 & 156 & 73.58 & 725 & 58.42 \\
\hline No & 377 & 66.26 & 123 & 78.85 & 500 & 68.97 \\
\hline
\end{tabular}




\begin{tabular}{|c|c|c|c|c|c|c|}
\hline Yes & 192 & 33.74 & 33 & 21.15 & 225 & 31.03 \\
\hline Male & 449 & 44.11 & 67 & 31.6 & 516 & 41.58 \\
\hline No & 334 & 74.39 & 55 & 82.09 & 389 & 75.39 \\
\hline Yes & 115 & 25.61 & 12 & 17.91 & 127 & 24.61 \\
\hline
\end{tabular}

Group or one-on-one interactions are both thought to be effective ways to improve the learner-teacher relationship. Group discussion can be used to collaborate with a group of individuals on activities such as debates, case studies, illustration, role-playing, and so on. Table-9 describes various methods that teachers employ to educate their students using group or one-to-one discussion. In rural places for oneon-one or group discussions with their pupils, $51.65 \%$ of teachers use Google Meet, $2.93 \%$ use Google Duo, $8.06 \%$ use WhatsApp Video Call, $1.1 \%$ use Skype, $17.95 \%$ use others, and $18.32 \%$ do not use any technology. In suburban areas $53.52 \%$ of teachers use Google Meet, $6.34 \%$ use WhatsApp video call, $2.82 \%$ use Google Duo, $19.72 \%$ use another alternative, and 17.61 do not use any method. In cities, $54.15 \%$ of teachers use Google Meet, $5.64 \%$ use WhatsApp video calls, $3.22 \%$ use Google Duo, $0.48 \%$ use Skype, $17.89 \%$ use other methods, and $18.94 \%$ do not engage one-on-one or group discussions with their students.

Table 9: Students view the option used by the teachers for an interactive 1-1 or group discussion

\begin{tabular}{|l|r|r|r|r|r|r|r|r|}
\hline \multicolumn{1}{|c|}{ Options } & Rural & \multicolumn{1}{c|}{$\%$} & Suburban & \multicolumn{1}{c|}{ U } & Urban & \multicolumn{1}{c|}{ T } & \multicolumn{1}{c|}{ Total } & \multicolumn{1}{c|}{} \\
\hline Google Duo & 8 & 2.93 & 4 & 2.82 & 28 & 3.41 & 40 & 3.22 \\
\hline Google Meet & 141 & 51.65 & 76 & 53.52 & 454 & 55.23 & 672 & 54.15 \\
\hline None & 50 & 18.32 & 25 & 17.61 & 157 & 19.1 & 235 & 18.94 \\
\hline Skype & 3 & 1.1 & 0 & 0 & 3 & 0.36 & 6 & 0.48 \\
\hline WhatsApp Video Call & 22 & 8.06 & 9 & 6.34 & 39 & 4.74 & 70 & 5.64 \\
\hline Others & 49 & 17.95 & 28 & 19.72 & 145 & 17.64 & 222 & 17.89 \\
\hline
\end{tabular}

Teachers can use the learning management system (LMS) to create and manage online classes. The learning management system (LMS) provides a centralized framework for streamlining all learning activities. Teachers can post-digital learning materials, assignments, quizzes, and other materials to the LMS, while students can provide feedback and upload homework. The LMS also makes it simple to evaluate the pupils' progress. The table-10 summarizes students' responses about the LMS used by their teachers. According to the survey, $1.29 \%$ of teachers use EasyClass, $83.56 \%$ use Google classroom, $1.53 \%$ use Moodle, $0.89 \%$ use Schoolgy, $7.82 \%$ use some other LMS and $4.92 \%$ do not use any LMS when handling online classes. Since Google Classroom is simple, easy and cost-effective, it is being extensively used by the majority of teachers. Setting up and managing classes does not require too much expertise.

Table 10: Students response about the Learning Management System (LMS) did the teachers use to set up an online classroom

\begin{tabular}{|l|r|r|}
\hline Options & Frequency & \multicolumn{1}{|c|}{$\%$} \\
\hline EasyClass & 16 & 1.29 \\
\hline Google Classroom & 1037 & 83.56 \\
\hline Moodle & 19 & 1.53 \\
\hline None & 61 & 4.92 \\
\hline Schoolgy & 11 & 0.89 \\
\hline Others & 97 & 7.82 \\
\hline
\end{tabular}

Because online learning does not allow for face-to-face communication, some degree of interaction can be achieved using email. The majority of the learning management system's activities are only communicated by e-mail. Instructors can use email to provide information about their weekly assignments, plans for the next week, and so on. Despite the availability of texting, instant messaging, 
and social media, students and teachers continue to favor email as the formal medium of contact. The many email services used by teachers to communicate with their students during online classes are displayed in Table-11. 79.69\% use Gmail, 4.83\% use institution-specific e-mail, 0.32\% use Outlook, $0.4 \%$ use Yahoo Mail, $7.33 \%$ use some other email options and $7.41 \%$ do not use any email service to communicate with their teachers. This shows the popularity of Gmail. Setting up of new Gmail account is very easy as the interface is much user-friendly. As some online services are integrated using Gmail, it saves users from remembering or recording several user names and passwords.

Table 11: Students' feedback about the email option used to remain in contact with the teachers.

\begin{tabular}{|l|r|r|}
\hline Options & Frequency & \multicolumn{1}{l|}{$\%$} \\
\hline Gmail & 989 & 79.69 \\
\hline Institution specific & 60 & 4.83 \\
\hline None & 92 & 7.41 \\
\hline Outlook & 4 & 0.32 \\
\hline Yahoo Mail & 5 & 0.4 \\
\hline Others & 91 & 7.33 \\
\hline
\end{tabular}

Videos can aid online learning in a variety of ways. They are thought to be an effective teaching tool, particularly in online learning. Apart from that, they can be utilized to boost motivation and generate a feeling of presence. The videos are extremely useful for learners who are unable to attend live sessions. Table-12 displays data from various video-sharing services utilized by teachers. $75.66 \%$ of professors post videos on YouTube and share the links with learners, 0.04\% use Facebook Watch to upload the videos, $0.24 \%$ use Yahoo Sites and Vimeo, $16.6 \%$ use some other platforms and $6.85 \%$ do not use any platform. The majority of teachers employ YouTube to share their films because it is a free and simple platform. It is simple to construct video tutorials, but to make them more effective, careful planning is required. Teachers and students can quickly create channels and save videos for later use. It is possible to integrate a wide range of authoring tools and LMS with the aid of YouTube.

Table 12: Students feedback about the Video sharing platform teachers prominently use?

\begin{tabular}{|l|r|r|}
\hline \multicolumn{1}{|c|}{ Options } & Frequency & \multicolumn{1}{c|}{$\%$} \\
\hline Facebook Watch & 5 & 0.4 \\
\hline None & 85 & 6.85 \\
\hline Vimeo & 3 & 0.24 \\
\hline Yahoo Sites & 3 & 0.24 \\
\hline YouTube & 939 & 75.66 \\
\hline Others & 206 & 16.6 \\
\hline
\end{tabular}

Exams are always part of education. During the pandemic period, students cannot take the traditional mode of exams. But the performance of the students has to be evaluated to measure the quality of education, levels of improvements in their knowledge, and outcome of the students. COVID-19 outbreak forced to conduct online exams through quizzes built using tools like Google forms, surveys, etc. The survey revealed this fact by collecting 919 (74.05\%) data by saying that Google forms, 20 $(1.61 \%)$ by Live Survey, 36(2.90\%) through Microsoft Forms, $7(0.56 \%)$ have taken using Survey Monkeys, $110(8.86 \%)$ are not using any of such exam tools. But $149(12.01 \%)$ of teachers are conducting exams using some other tools which were not the options given to them in the survey. Hence analysis (figure-3) found that the most common options used by teachers for conducting online exams are through Google forms and quizzes using such forms. 


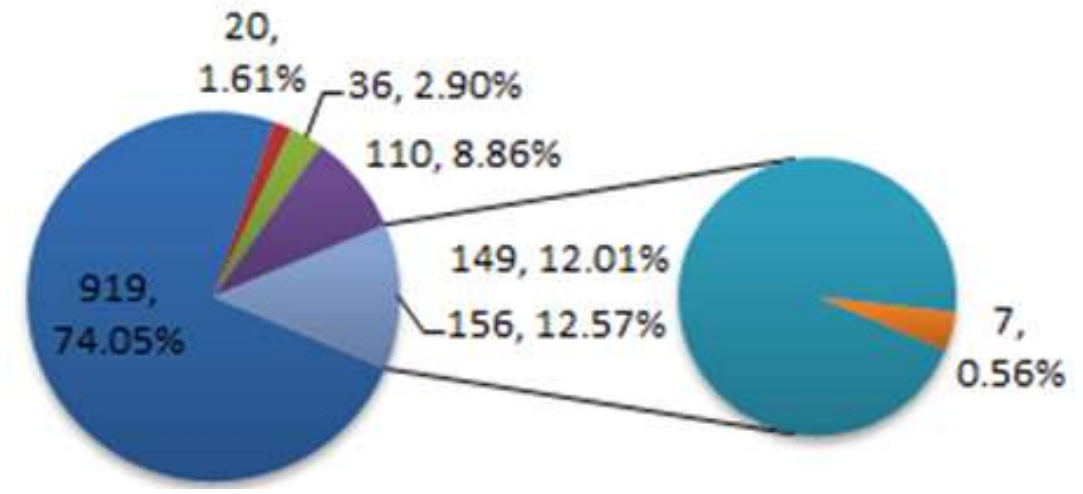

Fig 3: Students opinion about the options teachers prominently use for online forms/surveys/Quizzes

Students understand subjects by using the verbal and visual modes of teaching. Some students and subjects require these two modes together in the learning process. Hence sharing video is the main part of the online learning process. The survey data (Table-13) highlights 939(75.66\%) of teachers are sharing video through YouTube, 5(0.4\%) are by Facebook Watch, Vimeo and Yahoo sites are used by $3(0.24 \%)$ of teachers, and $206(16.6 \%)$ of them are using other tools which are not given in the choices given to them. It also revealed that $85(6.85 \%)$ of teachers are not going to share any of the videos and they are teaching only through audio or text-based classes.

Table 13: Platform used by teachers prominently for video sharing

\begin{tabular}{|l|r|r|}
\hline Options & Count & $\%$ \\
\hline Facebook Watch & 5 & 0.4 \\
\hline Vimeo & 3 & 0.24 \\
\hline Yahoo Sites & 3 & 0.24 \\
\hline YouTube & 939 & 75.66 \\
\hline Others & 206 & 16.6 \\
\hline None & 85 & 6.85 \\
\hline
\end{tabular}

Online education has the limitation of face-to-face communication during live classes or classes through video. Sometimes students may get doubts or teachers need to contact students to communicate some information, they need to use some email services. According to the data collected, figure-4 shows that 988(79.61\%) of them are using Gmail service, 60(4.83\%) of them are contacting through institutionspecific mail service, outlook express is the service for $4(0.32 \%), 5(0.4 \%)$ of them are communicating through yahoo mail services and 91 (7.33\%) of them are using other email services. But still, 92(7.41\%) users are not using any of these email services for communication during the online education environment. This analysis proved that Gmail services are the most common service used by most of the stakeholders involved in online education.

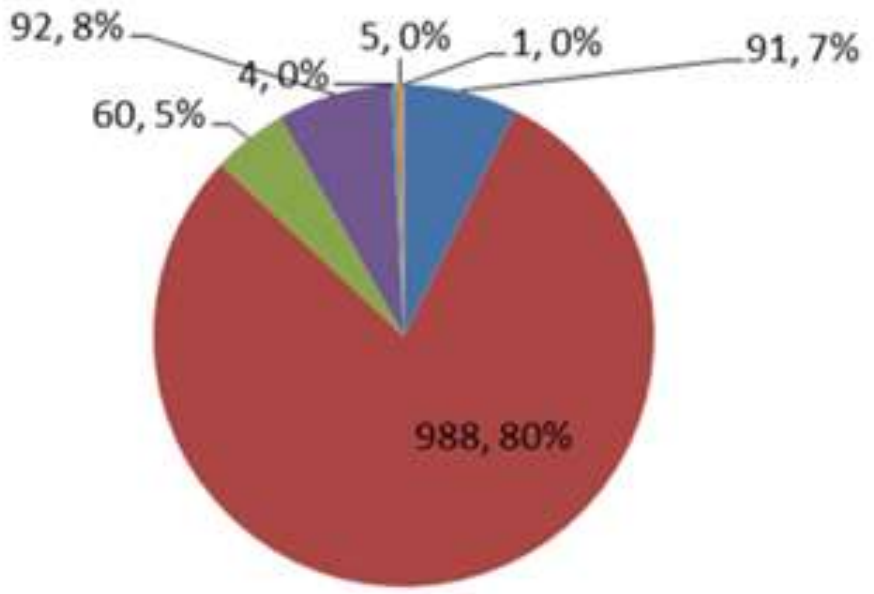

Fig. 4: Email service used by teachers to contact 


\section{TESTING OF HYPOTHESIS :}

Using the Chi-Square Test statistical model, the hypotheses were tested. The chi-squared test (symbolized as $\mathrm{X}^{2}$ ) is a data analysis based on random observations of a set of variables [32]. It is typically a comparison of two sets of statistical data. By assuming that the null hypothesis is true, the chi-square test is used to determine how likely the observations are. The formula for chi-square can be written as:

$$
\chi^{2}=\sum(O-E)^{2} / E
$$

The observed frequency is denoted by the letter $\mathrm{O}$. E is the null hypothesis' expected frequency, which is calculated as follows:

$$
E=\frac{\text { row total } \times \text { column total }}{\text { sample size }}
$$

When the null hypothesis is true, the test statistic's sample distribution is known as the chi-squared distribution. The two categorical variables are independent under the Null Hypothesis. Hypothesis testing is a technique for rejecting a null hypothesis with a given level of confidence. The null hypothesis is tested with a p-value of .05 to see if there is evidence against it [33].

In one or more classes or categories, the chi-squared test can be used to see if there is a significant difference between the normal and observed frequencies. It expresses the likelihood of independent variables. Probability is represented by the letter $\mathrm{P}$ in this equation. The chi-square test is employed in statistics to compute the p-value [34].

The various $\mathrm{p}$ values that correspond to different hypothesis interpretations are given below:

$\mathrm{P} \leq .05 ;$ Hypothesis rejected

$\mathrm{P}>.05$; Hypothesis accepted

The online Chi-Square Test Calculator provided by Social Science Statistics (https://www.socscistatistics. com/tests/chisquare2/default2.aspx) is used to perform the chi-square test with data samples.

\section{$\mathrm{H}_{1}$ : Google does not play a significant role in the field of online education.}

The observed cell totals, (anticipated cell totals), and [the chi-square statistic for each cell] are all listed in the contingency table (Table-14) below.

Table 14: The contingency table -I

\begin{tabular}{|l|l|l|}
\hline \multicolumn{1}{|c|}{ Google } & \multicolumn{1}{c|}{ Others } \\
\hline Online Forms & $919(910.80)[0.07]$ & $322(330.20)[0.20]$ \\
\hline Video Sharing & $939(910.80)[0.87]$ & $302(330.20)[2.41]$ \\
\hline Web Mail & $988(910.80)[6.54]$ & $253(330.20)[18.05]$ \\
\hline Virtual Classroom & $1036(910.80)[17.21]$ & $205(330.20)[47.47]$ \\
\hline Video Meeting & $672(910.80)[62.61]$ & $569(330.20)[172.70]$ \\
\hline File Sharing & $921(777.00)[26.69]$ & $320(464.00)[44.69]$ \\
\hline Online Documents & $850(777.00)[6.86]$ & $391(464.00)[11.48]$ \\
\hline Online Calendar & $560(777.00)[60.60]$ & $681(464.00)[101.48]$ \\
\hline
\end{tabular}

The calculated chi-square statistic is 328.1432 and the p-value is .00001 . Therefore, the result is significant at $\mathrm{p}<.05$. Hence the null hypothesis is rejected.

$\mathrm{H}_{2}$ : There is no significant difference among male and female students' perceptions of oncampus education as their preferred mode of education.

The observed cell totals, (anticipated cell totals), and [the chi-square statistic for each cell] are all listed in the contingency table (Table-15) below.

Table 15: The contingency table -II

\begin{tabular}{|l|l|l|}
\hline \multicolumn{1}{|c|}{} & \multicolumn{1}{|c|}{ Male } & \multicolumn{1}{c|}{ Female } \\
\hline On-Campus & $364(367.98)[0.04]$ & $521(517.02)[0.03]$ \\
\hline Online & $81(79.00)[0.05]$ & $109(111.00)[0.04]$ \\
\hline Blended & $71(69.02)[0.06]$ & $95(96.98)[0.04]$ \\
\hline
\end{tabular}


The calculated chi-square statistic is 0.2572 and the p-value is .879307 . Therefore, the result is not significant at $\mathrm{p}<.05$. Hence the null hypothesis is accepted.

$\mathrm{H}_{3}$ : There is a significant difference in perceptions of WhatApp as the preferred medium for communication with teachers among male and female students.

The observed cell totals, (anticipated cell totals), and [the chi-square statistic for each cell] are all listed in the contingency table (Table-16) below.

Table 16: The contingency table -III

\begin{tabular}{|l|l|l|}
\hline & \multicolumn{1}{|c|}{ Male } & \multicolumn{1}{c|}{ Female } \\
\hline WhatsApp & $486(494.38)[0.14]$ & $703(694.62)[0.10]$ \\
\hline Others & $30(21.62)[3.25]$ & $22(30.38)[2.31]$ \\
\hline
\end{tabular}

The calculated chi-square statistic is 5.8009 and the p-value is .016018. Therefore, the result is significant at $\mathrm{p}<.05$. Hence the null hypothesis is rejected [35].

\section{FINDINGS :}

The results of this study show that employing online mode during the challenging situation of the COVID-19 pandemic was the proper decision because the traditional way was not feasible. With educational institutions closing, students believe that online education is a wonderful concept because it allows them to receive an education without having to leave their homes. The availability of network connectivity in rural and suburban regions is a difficulty for this learning technique. The following are some of the study's findings:

- Educators mostly use Google products to provide online education. Teachers use Google Classroom to simulate a real classroom environment (84\%), Google Forms to conduct simple online tests, quizzes, and collect feedback (74\%), YouTube to share recoded video classes (76\%), Google Mail to communicate with students and share information (79\%), Google Drive to share files (74\%), Google Docs (68 percent) to produce and share documents including word processing, presentations, and spreadsheets, Google Meet (54\%) is used for online meetings and live classes and Google Calendar is used to communicate class schedules (45\%).

- During the COVID-19 pandemic, both synchronous and asynchronous modalities of online teaching are used equally. Many teachers provided both types of education.

- Students are self-sufficient in terms of the devices they use to take online classes, with a large percentage of students attending online classes using their smartphones. A substantial percentage of students utilize mobile data to connect their devices to the internet when participating in online education. The network is thought to be their greatest impediment to participation.

- During online education, teachers use varied modes to assess students' progress. Exams written offline and scanned response scripts uploaded, online quizzes, exams using dedicated exam software, writing the test in front of a live camera and then uploading the scanned responses, and open book exams are among their alternatives.

- During this pandemic, a large number of students are entirely or partially satisfied with the effectiveness of online education. But students are not convinced that online education would improve their learning experience. Female students, in particular, find online education to be more convenient than male students. Female students spend more time on online education activities than male ones.

- Students are not fully convinced with the technology and tools used by teachers to deliver online education. They believe that face-to-face communication is essential for online learning to succeed. Despite the pandemic, students think their parents are supportive in every manner during online education.

- Students believe that online education teaches them less than on-campus education. Also, they felt that in online classrooms they had less opportunity to express themselves than in on-campus 
classes. Moreover, the online education provided them with insufficient practical and theoretical experience, they felt.

- WhatsApp is the most widely used platform for students and teachers to communicate. A whopping $96 \%$ of students use this method to communicate with their teachers.

- The students' opinions on traditional instruction in physical classrooms are plain. When compared to online and mixed-modal learning, they believe it is the most effective medium of instruction.

\section{RECOMMENDATIONS :}

Learning is a never-ending journey for an aspirant of knowledge. Challenges must be transformed into opportunities by developing new methods for overcoming them. The COVID-19 pandemic is an example of a situation in which students and teachers are unable to participate in the traditional, faceto-face, on-campus learning environment. Higher education institutions must find a mode of online education using numerous technologies and applications available on the internet to complete the curriculum. Among such applications, the Google platform and the majority of Google's tools and applications are the most common examples. As a result, institutions encourage students, teachers, and parents to use Google applications with their smartphones, PCs, or laptops to conduct online classes.

- Institutions must provide regular training to teachers and students for them to use such online applications in online classes and communication.

- While taking online classes, more flexibility, operations, and comfort are required. As a result, institutions should support free, paid, and updated versions of online products to ensure that classes run as smoothly as traditional classes.

- Most students in rural and semi-urban areas are experiencing network issues that prevent them from actively participating in online education. As a result, in the future, if internet connections improve, online learning will be the best mode of education while sitting at home.

- The same software and tools will not be used to teach theory and practical subjects. Theory papers necessitate the use of adaptable and visually appealing tools such as Google Maps and Earth. More tools, such as simulations and virtual labs, are required for practical papers and projects.

- Subjects and classes will suffer as a result of a lack of communication. To improve the quality of the teaching and learning experience, sophisticated online tools that provide flexible and user-friendly communication facilities are always required.

- Exams are an unavoidable part of education to promote students. Also, students' knowledge is measured, and plagiarism is always a major challenge during online exams. As a result, more sophisticated, cost-effective products and tools must be considered to provide justice to students.

- Knowledge seekers will not be satisfied by either offline or online education alone. To improve educational quality, students will be required to engage in blended learning in the future.

\section{CONCLUSION :}

During a COVID-19 outbreak, people are being forced to go into lockdown to prevent the spread of infectious diseases. Because schools and colleges are closed indefinitely, both organizations and students are exploring new ways of learning in an attempt to reach the educational curriculum. Such measures have undoubtedly caused some annoyance, but they have also triggered new examples of innovation systems utilizing digital interventions. Recent technological advancements have opened up new avenues for learning and teaching. The majority of Google's tools and applications have attracted the attention of more people in online learning. Taking full advantage of such Google tools necessitates new ways of thinking about teaching and learning, as well as the establishment of benchmarks to guarantee the effectiveness of online learning.

According to the survey, the Internet and traditional classroom methods of teaching are not mutually exclusive, but rather should be viewed as an additional dimension in learning that can help the teacher's job while also benefiting the students. It is noticeable that both teachers and learners need to improve their technical knowledge. When asked to rate the overall quality of the online education they received, participants gave moderate ratings. Moderate online learning quality implies that they were dissatisfied 
with the education they received or did not perceive the online education they received to be of great quality. The participants' personalities may have had an impact on how accountable they felt for their learning. To reap the benefits of online learning, online learners may have to modify their behavior patterns, such as a lack of self-motivation and not being a passive and active learners.

\section{Acknowledgment:}

We do want to thank all of the undergraduate and postgraduate students who participated in the survey. Prof. Ganapathy S., Former HoD., Department of Economics, St Philomena College, Puttur, and Prof. Shashidhar Kotian, Professor, Research, Srinivas University, Mangalore, for their assistance with survey design and statistical analysis. All survey participants used in this study agreed to have their responses evaluated as part of the study.

\section{REFERENCES :}

[1] Helmi, A. (2001). An analysis on the impetus of online education: Curtin University of Technology, Western Australia. The Internet and Higher Education, 4(3-4), 243-253

[2] Volery, T., \& Lord, D. (2000). Critical success factors in online education. International Journal of Educational Management, 14(5), 216-223

[3] Volery, T. (2001). Online Education: An Exploratory Study into Success Factors. Journal of Educational Computing Research, 24(1), 1-16.

[4] Krishna Prasad, K., Aithal, P. S., Geetha Poornima, K., \& Vinayachandra, (2021). An AI-based Analysis of the effect of COVID-19 Stringency Index on Infection rates: A case of India. International Journal of Health Sciences and Pharmacy (IJHSP), 5(1), 87-102.

[5] Krishna Prasad, K., Vinayachandra, Geetha Poornima, K. \& Rajeshwari, M. (2020). Effect of COVID-19 on Technology Penetration: a Predictive Analysis. Alochana Chakra Journal, 9(5), 2949-2967.

[6] Karakaya, F., Selçuk, A. R. I. K., Cimen, O., \& Yilmaz, M. (2020). Investigation of the views of biology teachers on distance education during the COVID-19 pandemic. Journal of Education in Science Environment and Health, 6(4), 246-258.

[7] Yang, Y., \& Cornelius, L. F. (2004). Students' perceptions towards the quality of online education: A qualitative approach. Association for Educational Communications and Technology, 27th, Chicago, IL. IL., October, 19-23.

[8] Garg, M. (2018). Student satisfaction as determinant of academic success of distance learners: A study across distance learning courses. The Online Journal of Distance Education and eLearning, 6(3), 30-43.

[9] Geetha Poornima, K, Rajeshwari, M, Vinayachandra, \& Krishna Prasad, K. (2020). Integration of Adaptive Technologies with Healthcare for the Early Identification and Control of COVID-19 Pandemic Disease. International Journal of Health Sciences and Pharmacy (IJHSP), 4(2), 5-28.

[10] Vinayachandra, Geetha Poornima K., Rajeshwari, M. \& Krishna Prasad, K. (2021). Students' Perception of the Effectiveness of Technology Assisted Online Education During COVID-19 Pandemic: An Empirical Study. International Journal of Management, Technology, and Social Sciences (IJMTS), 6(1), 203-225.

[11] Adapa, S. (2015). Three-step approach for developing integrated work-ready assessment tools to foster students learning and satisfaction. Educational Research and Reviews, 10(9), 1347-1353

[12] Brown, M. E., \& Hocutt, D. L. (2015). Learning to use, useful for learning: a usability study of Google apps for education. Journal of Usability Studies, 10(4), 160-181. 
[13] Versteijlen, M., Salgado, F. P., Groesbeek, M. J., \& Counotte, A. (2017). Pros and cons of online education as a measure to reduce carbon emissions in higher education in the Netherlands. Current opinion in environmental sustainability, 28(1), 80-89.

[14] Iftakhar, S. (2016). Google classroom: what works and how. Journal of Education and Social Sciences, 3(1), 12-18.

[15] Jindal, A., \& Chahal, B. P. S. (2018). Challenges and Opportunities for Online Education in India. Pramana Research Journal, 8(4), 99-106.

[16] Bhagat, K. K., Wu, L. Y., \& Chang, C. Y. (2019). The impact of personality on students' perceptions towards online learning. Australasian Journal of Educational Technology, 35(4), 98108 .

[17] Ghazi-Saidi, L., Criffield, A., Kracl, C. L., McKelvey, M., Obasi, S. N., \& Vu, P. (2020). Moving from face-to-face to remote instruction in a higher education institution during a pandemic: Multiple case studies. International Journal of Technology in Education and Science, 4(4), 370383.

[18] Li, C. H., Rajamohan, A. G., Acharya, P. T., Liu, C. S. J., Patel, V., Go, J. L., Kim, P. E., \& Acharya, J. (2020). Virtual Read-Out: Radiology Education for the 21st Century During the COVID-19 Pandemic. Academic Radiology, 27(6), 872-881.

[19] Basilaia, G., \& Kvavadze, D. (2020). Transition to Online Education in Schools during a SARSCoV-2 Coronavirus (COVID-19) Pandemic in Georgia. Pedagogical Research, 5(4), 1-9.

[20] Chen, T., Cong, G., Peng, L., Yin, X., Rong, J., \& Yang, J. (2020). Analysis of user satisfaction with online education platforms in china during the covid-19 pandemic. Healthcare (Switzerland), 8(3), 200-226.

[21] Yaman, N., \& Muhlis, M. (2020). Students Social Presence and Perceived Learning toward CCU Course in online Classroom (An Evaluating of Learning Process during Pandemic Coronavirus). Elite English and Literature Journal, 7(1), 61-73.

[22] Laksana, D. N. L. (2021). Implementation of online learning in the pandemic covid-19: Student perception in areas with minimum internet access. Journal of Education Technology, 4(4), 502509.

[23] Krutka, D. G., Smits, R. M., \& Willhelm, T. A. (2021). Don't Be Evil: Should We Use Google in Schools?. TechTrends, 65(1), 421-431.

[24] Coman, C., Țîru, L. G., Meseșan-Schmitz, L., Stanciu, C., \& Bularca, M. C. (2020). Online teaching and learning in higher education during the coronavirus pandemic: Students' perspective. Sustainability (Switzerland), 12(24), 1-22.

[25] Mishra, L., Gupta, T., \& Shree, A. (2020). Online teaching-learning in higher education during lockdown period of COVID-19 pandemic. International Journal of Educational Research Open, $1(1), 1-8$.

[26] Muthuprasad, T., Aiswarya, S., Aditya, K. S., \& Jha, G. K. (2021). Students' perception and preference for online education in India during COVID -19 pandemic. Social Sciences \& Humanities Open, 3(1), 1-11

[27] Tang, Y. M., Chen, P. C., Law, K. M., Wu, C. H., Lau, Y. Y., Guan, J., ... \& Ho, G. T. (2021). Comparative analysis of Student's live online learning readiness during the coronavirus (COVID19) pandemic in the higher education sector. Computers \& Education, 168(1), 1-17.

[28] Paudel, P. (2021). Online education: Benefits, challenges and strategies during and after COVID19 in higher education. International Journal on Studies in Education, 3(2), 70-85. 
[29] Smart, K. L., \& Cappel, J. J. (2006). Students' perceptions of online learning: A comparative study. Journal of Information Technology Education: Research, 5(1), 201-219.

[30] Sandhya, S., Koppad, S. H., Kumar, S. A., Dharani, A., Uma, B. V., \& Subramanya, K. N. (2020). Adoption of Google Forms for enhancing collaborative stakeholder engagement in higher education. Journal of Engineering Education Transformations, 33(1), 283-289.

[31] Awuah, L. (2015). Supporting 21st-Century Teaching and Learning: The Role of Google Apps for Education. Journal of Instructional Research, 4(2015), 12-22.

[32] Zibran, M. F. (2007). Chi-squared test of independence. Department of Computer Science, University of Calgary, Alberta, Canada, 1(1), 1-7.

[33] Aithal, P. S., \& Aithal, S. (2019). Management of ICCT underlying Technologies used for Digital Service Innovation. International Journal of Management, Technology, and Social Sciences (IJMTS), 4(2), 110-136.

[34] Rana R, Singhal R. (2015). Chi-square test and its application in hypothesis testing. J Pract Cardiovasc Sci., 1(1). 69-71

[35] McHugh M. L. (2013). The chi-square test of independence. Biochemia medica, 23(2), 143-149. 